\title{
Detailed Investigations on Cytotaxonomical Perspectives in Nitella hyalina Complex (Charales: Charophyceae)
}

\author{
H. S. Pundhir* and A. K. S. Chauhan \\ Department of Botany, D.S. College, Aligarh-202001, India \\ Accepted February 5, 2001
}

\begin{abstract}
Summary Present paper deals with the detailed morphological, cytological and cytotaxonomical studies on 3 cytotypes of $N$. hyalina $\mathrm{f}$. hyalina, collected from Mudasarilova tank (Visakhapatnam), Sakhya Sagar dam (Shivpuri) and Tighra dam (Gwalior). The cytological preparations reveal the occurrence of chromosomes counts of $n=15,18$ and 21, respectively. Count of 3 chromosomes numbers in 3 different cytotypes clearly established polyploidy in this taxon, if $x=3$ considered as the ancestral number. It was found that polyploidy is certainly associated with the morphological diversifications. As the chromosome numbers increased certain additional characters appeared, while, with reduction in chromosome numbers these additional characters have not been observed.
\end{abstract}

Key words Cytology, Cytotaxonomy, Nitella hyalina f. hyalina, Chromosome counts, Polyploidy

The tribe Nitelleae of the order Charales (Class Charophyceae) constitute an interesting group of green algae, showing some unique characteristic features like uncorticated plant body, monopodially divided branchlet furcations and lateral oogonia with 10-celled coronula in 2-tiers. Systematics of this group was widely described by Faridi (1956), Wood (1965), Corillion and Guerlesquin (1972), Caceres (1975), Compere (1982), Fu-shan and Hualong (1982), Comelles (1984), Hotchkiss and Imahori (1987), Pundhir et al. (1994) and others. Although large number of species of this group were studied for their cytology by several workers such as Gillet (1959), Sawa (1965), Khan and Sarma (1967a), Kanahori (1971), Mukherjee and Noor (1973), Ray and Chatterjee (1988), Pundhir and Gautam (1993) and Pundhir et al. (1993), very few attempts have been made to analyse them cytosystematically. In the present investigation, detailed cytotaxonomical studies were carried out on 3 cytotypes of Nitella hyalina (DeCandolle) Agardh $\mathrm{f}$. hyalina found at 3 different ploidy level exhibited interesting correlations between cytotaxonomical and morphological characters.

\section{Materials and methods}

Living specimens of Nitella hyalina f. hyalina were collected from Mudasarilova tank (Visakhapatnam), Sakhya Sagar dam (Shivpuri) and Tighra dam (Gwalior), during Dec. 1991 to Jan. 1992. Young growing fertile upper healthy tips were fixed in absolute alcohol glacial acetic acid $(3: 1)$ for cytological studies. Plants were further preserved in $4 \%$ formalin for morphological observations. Identification was made following Wood (1965). Godward's (1948) iron-alum acetocarmine technique was employed for squashing spermatogenous antheridial filaments. Chromosome numbers were determined at metaphase when the chromosomes are found to be highly condensed and well spread. Camera lucida drawings and corresponding photographs were taken from temporary preparations. Slides were made permanent using propionic acid-butanol series and mounted in euperal. Voucher specimens and permanent slides are deposited in Cytology Laboratory, D.S. College, Aligarh (U.P.), India.

\footnotetext{
* Corresponding author, permanent address: Rohina Singh Pur, Khera Narain Singh, Aligarh-202121 (U.P.), India.
} 
Table 1. Comparative morphology of Nitella hyalina (DeCandolle) Agardh f. hyalina

\begin{tabular}{|c|c|c|c|c|}
\hline Plant parts & Tighra plants & Mudasarilova plants & Sakhya Sagar plants & Wood (1965) \\
\hline Plant sex & Monoecious & Monoecious & Monoecious & Monoecious \\
\hline Plants height & $\begin{array}{l}\text { Upto } 8.0 \mathrm{~cm} \text {, small to } \\
\text { medium in size }\end{array}$ & $\begin{array}{l}\text { Upto } 14 \mathrm{~cm} \text {, small } \\
\text { to medium in size }\end{array}$ & $\begin{array}{l}\text { Upto } 4.0 \mathrm{~cm} \text {, small } \\
\text { size }\end{array}$ & Medium size \\
\hline Mucus presence & $\begin{array}{l}\text { Upper whorls cov- } \\
\text { ered with mucus }\end{array}$ & $\begin{array}{l}\text { Upper whorls } \\
\text { densely covered } \\
\text { with mucus }\end{array}$ & $\begin{array}{l}\text { Whole plant body } \\
\text { densely covered } \\
\text { with mucus }\end{array}$ & $\begin{array}{l}\text { Upper whorls often } \\
\text { crowded and covered } \\
\text { with mucus }\end{array}$ \\
\hline Axes & Slender & Slender & Slender & Slender \\
\hline Axial diameter & $390-420 \mu \mathrm{m}$ & $270-295 \mu \mathrm{m}$ & $285-375 \mu \mathrm{m}$ & $220-500 \mu \mathrm{m}$ \\
\hline Internodes & $\begin{array}{l}1-4 \text { times as } \\
\text { long as the } \\
\text { branchlets }\end{array}$ & $\begin{array}{l}1-8 \text { times as long } \\
\text { as the branchlets }\end{array}$ & $\begin{array}{l}\text { Shorter to } 2 \text { times } \\
\text { as long as the } \\
\text { branchlets }\end{array}$ & $\begin{array}{l}2-4 \text { times as long as } \\
\text { the branchlets }\end{array}$ \\
\hline Branchlets & $\begin{array}{l}\text { Heteroclemous, } \\
\text { fertiles } 8 \text { in } \\
\text { a whorl }\end{array}$ & $\begin{array}{l}\text { Heteroclemous, } \\
\text { fertiles } 8 \text { in a } \\
\text { whorl }\end{array}$ & $\begin{array}{l}\text { Heteroclemous, } \\
\text { fertiles } 8 \text { in a } \\
\text { whorl }\end{array}$ & $\begin{array}{l}\text { Heteroclemous, } \\
\text { fertiles } 8 \text { in a whorl }\end{array}$ \\
\hline Furcations & 2-4 furcated & 3-4 furcated & 2-3 furcated & $2-3(-4)$ furcated \\
\hline Primary rays & $\begin{array}{l}2 / 3-3 / 4 \text { times } \\
\text { of branchlets }\end{array}$ & $\begin{array}{l}1 / 2-3 / 4 \text { times of } \\
\text { branchlets }\end{array}$ & $\begin{array}{l}3 / 5-3 / 4 \text { times of } \\
\text { branchlets }\end{array}$ & $\begin{array}{l}1 / 2-3 / 5 \text { times of } \\
\text { branchlets }\end{array}$ \\
\hline Secondary rays & $\begin{array}{l}7-8 \text { (of which } 1-2 \\
\text { may unfurcated) } \\
\text { with percurrent } \\
\text { central axis which } \\
\text { developed into } \\
\text { branchlets }\end{array}$ & $\begin{array}{l}8 \text { of which all are } \\
\text { furcated }\end{array}$ & $\begin{array}{l}8-10 \text { of which } 2- \\
4 \text { unfurcated with } \\
\text { one central } \\
\text { antheridium instead } \\
\text { of percurrent } \\
\text { central axis }\end{array}$ & $\begin{array}{l}7-10 \text { of which } 1-3 \\
\text { are simple }\end{array}$ \\
\hline Tertiary rays & $\begin{array}{l}5-7 \text { of which } 3-5 \\
\text { unfurcated }\end{array}$ & $\begin{array}{l}6-8 \text { of which } 3 \text { are } \\
\text { simple }\end{array}$ & $\begin{array}{l}6 \text { of which } 4-5 \\
\text { unfurcated }\end{array}$ & $\begin{array}{l}4-7 \text { of which } 1-2 \\
\text { may unfurcate }\end{array}$ \\
\hline Quaternary rays & $5-6$ & $\begin{array}{l}6 \text { of which 1-2 } \\
\text { furcated }\end{array}$ & 6 & $4-5$ \\
\hline Quanary rays & $3-5$ & $4-6$ & - & - \\
\hline Dactyls & $\begin{array}{l}3-5,2 \text {-celled; end } \\
\text { cell conical, acute, } \\
\text { very much reduced, } \\
\text { mucronate }\end{array}$ & $\begin{array}{l}6,2 \text {-celled; end cell } \\
\text { conical, confluent }\end{array}$ & $\begin{array}{l}6,2 \text {-celled; end cell } \\
\text { conical, acute, } \\
\text { mucronate, } \\
\text { sometimes } \\
\text { confluent }\end{array}$ & $\begin{array}{l}\text { 4-6, 2-celled; end } \\
\text { cell conical, acute, } \\
\text { confluent }\end{array}$ \\
\hline Heads & $\begin{array}{l}\text { Terminal with dense } \\
\text { mucus }\end{array}$ & $\begin{array}{l}\text { Not formed, but } \\
\text { upper whorls } \\
\text { densely covered } \\
\text { with mucus }\end{array}$ & $\begin{array}{l}\text { Formed with } \\
\text { dense mucus }\end{array}$ & $\begin{array}{l}\text { Not formed, but } \\
\text { upper whorls may } \\
\text { become crowded and } \\
\text { often enveloped in mucus }\end{array}$ \\
\hline Gametangia & $\begin{array}{l}\text { Stalked, conjoined } \\
\text { or sejoined at 2-4 } \\
\text { nodes }\end{array}$ & $\begin{array}{l}\text { Sessile, conjoined } \\
\text { at all branchlet } \\
\text { furcations }\end{array}$ & $\begin{array}{l}\text { Stalked, conjoined } \\
\text { at } 2 \text { lowest branch- } \\
\text { let nodes }\end{array}$ & $\begin{array}{l}\text { Conjoined at all } \\
\text { branchlet furcations }\end{array}$ \\
\hline Oogonia & $\begin{array}{l}\text { Solitary, } 270- \\
420 \mu \mathrm{m} \text { long } \\
\text { (excl. coronula), } \\
225-345 \mu \mathrm{m} \text { wide, } \\
\text { convolutions } 8\end{array}$ & $\begin{array}{l}\text { Solitary, } 300-415 \\
\mu \mathrm{m} \text { long (excl. } \\
\text { coronula), } 285- \\
330 \mu \mathrm{m} \text { wide, } \\
\text { convolutions } 8\end{array}$ & $\begin{array}{l}\text { Solitary, } 270-420 \\
\mu \mathrm{m} \text { long (excl. coro- } \\
\text { nula), } 200-330 \mu \mathrm{m} \\
\text { wide, convolutions } \\
8-9\end{array}$ & $\begin{array}{l}\text { Solitary (rarely gemi- } \\
\text { nate), } 425-565 \mu \mathrm{m} \\
\text { long (excl. coronula), } \\
375-400 \mu \mathrm{m} \text { wide, } \\
\text { convolutions } 8\end{array}$ \\
\hline Coronula & $\begin{array}{l}\text { Unequal, } 30-45 \\
\mu \mathrm{m} \text { high, } 45-60 \\
\mu \mathrm{m} \text { wide }\end{array}$ & $\begin{array}{l}\text { Unequal, } 45-60 \\
\mu \mathrm{m} \text { high, } 45-60 \\
\mu \mathrm{m} \text { wide }\end{array}$ & $\begin{array}{l}\text { Unequal, } 30-45 \\
\mu \mathrm{m} \text { high, } 45-60 \\
\mu \mathrm{m} \text { wide }\end{array}$ & $\begin{array}{l}45-60 \mu \mathrm{m} \text { high, } \\
60 \mu \mathrm{m} \text { wide }\end{array}$ \\
\hline Oospores & $\begin{array}{l}\text { Dark brown, } 285- \\
330 \mu \mathrm{m} \text { long, } 240- \\
270 \mu \mathrm{m} \text { wide, striae } \\
6-7 \text { with prominent } \\
\text { ridges, membrane } \\
\text { reticulate }\end{array}$ & $\begin{array}{l}\text { Light brown to dark } \\
\text { brown, } 405-450 \mu \mathrm{m} \\
\text { long, } 300-345 \mu \mathrm{m} \\
\text { wide, striae } 6-7 \text { with } \\
\text { prominent ridges, } \\
\text { membrane granulate }\end{array}$ & - & $\begin{array}{l}\text { Reddish brown, } 300- \\
350 \mu \mathrm{m} \text { long, } 280- \\
320 \mu \mathrm{m} \text { wide, striae } \\
6-7 \text { with prominent } \\
\text { ridges, membrane } \\
\text { finely granulate }\end{array}$ \\
\hline Antheridia & $\begin{array}{l}285-345 \mu \mathrm{m} \text { in } \\
\text { diameter }\end{array}$ & $\begin{array}{l}270-360 \mu \mathrm{m} \text { in } \\
\text { diameter }\end{array}$ & $\begin{array}{l}270-345 \mu \mathrm{m} \text { in } \\
\text { diameter }\end{array}$ & $\begin{array}{l}350-425 \mu \mathrm{m} \text { in } \\
\text { diameter }\end{array}$ \\
\hline
\end{tabular}


Table 2. Comparative cytology and cytotaxonomy of Nitella hyalina (DeCandolle) Agardh $\mathrm{f}$. hyalina

\begin{tabular}{lccc}
\hline \multicolumn{1}{c}{ Characters } & Tighra plants & Mudasarilova plants & Sakhya Sagar plants \\
\hline Chromosome numbers & 15 & 18 & 21 \\
Cell's length $(\mu \mathrm{m})$ & $13.0-15.0$ & $13.0-18.0$ & $13.5-19.5$ \\
Cell's breadth $(\mu \mathrm{m})$ & $11.2-13.5$ & $12.6-15.2$ & $10.5-12.0$ \\
Chromocentres & 2 & $1-2$ & 2 \\
Nucleus diameter $(\mu \mathrm{m})$ & $6.0-13.5$ & $12.0-15.0$ & $9.0-10.5$ \\
Nucleolus number & 1 & $1-2$ & 1 \\
Nucleolus diameter $(\mu \mathrm{m})$ & $3.0-4.5$ & $4.2-4.5$ & $4.5-6.0$ \\
Chromosomes length $(\mu \mathrm{m})$ & $2.62-6.00$ & $1.37-3.12$ & $1.00-5.87$ \\
Chromosomes breadth $(\mu \mathrm{m})$ & $0.75-1.00$ & $0.62-0.87$ & $0.62-0.87$ \\
Metacentric chromosomes & - & 2 & 2 \\
Submetacentric chromosomes & 12 & 11 & 12 \\
Subtelocentric chromosomes & 1 & 1 & 1 \\
Telocentric chromosomes & 2 & 4 & 6 \\
\hline
\end{tabular}

\section{Results and discussion}

Morphological observations of all the 3 cytotypes are summarized in Table 1. Detailed comparative cytology and cytotaxonomy has been given in Table 2 .

Indian specimens belonging to Nitella hyalina f. hyalina are highly conspicuous having heteroclemous branchlets and arthrodactylous dactyls covered with thick layer of mucus which provided to these, a characteristic hyaline appearance (Table 1). They possess 2 rows of accessory branchlets in contrast to another heteroclemous species, N. stuartii (Wood 1965) which is having only 1 row of accessory branchlets and anarthrodactylous dactyls.

Three cytotypes of $N$. hyalina f. hyalina collected from Tighra dam, Mudasarilova tank and Sakhya Sagar dam were studied for their cytological features and revealed the occurrence of $n=15$ (Figs. 1, 2), $n=18$ (Figs. 3, 4) and $n=21$ (Figs. 5, 6) chromosomes, respectively. The count of $n=15$ in Tighra plants confirms the finding of Mukherjee (1978) and count of $n=21$ in Sakhya Sagar dam plants confirms the report of Bhatnagar (1988). The chromosome number $n=18$ determined for Mudasarilova plants is in agreement with the counts of Sato (1959), Guerlesquin (1961, 1963), Hotchkiss (1965), Sarma and Khan (1965), Khan and Sarma (1967b), Ramjee and Sarma (1971) and Ramjee and Bhatnagar (1978). The reports of $n=12$ (Sato 1959, Sinha and Verma 1970, Subramanian and Ganesan 1983), $n=12-14$ (Stewart 1937), $n=14$ (Sato 1959), $n=16$ (Gillet 1959) and $n=33$ (Das and Majumdar 1984) could not be confirmed in the present study. The count of different chromosome numbers $(n=15,18,21)$ during present study alongwith other counts $(n=12,33)$ (Sato 1959, Sinha and Verma 1970, Subramanian and Ganesan 1983, Das and Majumdar 1984) are fit in euploid series of $n=6,9,12,15,18,21,24,27,33,36,48$ and therefore, uphold the view of $x=3$ as the proposed basic chromosome number for this genus (Sarma and Khan 1964, 1965, Khan and Sarma 1967b). The count of $n=14$ by Stewart (1937) and Sato (1959) might be counting error or may be represent the heteroploidy in this taxon.

Gillet (1959) suggested $x=6$ as the basic chromosome number for Nitella which was supported by Hotchkiss (1963). Guerlesquin (1961) has, however, suggested 6 and 7 as the basic chromosome numbers for this genus. For arthrodactylous forms, an additional basic chromosome number $x=9$ was suggested by Hotchkiss (1963). But the occurrence of $n=9$ chromosome number in an anarthrodactylous form N. mirabilis reported by Ramjee and Bhatnagar (1978) contradicted the above generalization.

It is interesting to note that the cytological features other than chromosomal morphology and numbers, are, almost alike in the 3 populations of $N$. hyalina $\mathrm{f}$. hyalina. The chromosomes are fairly 

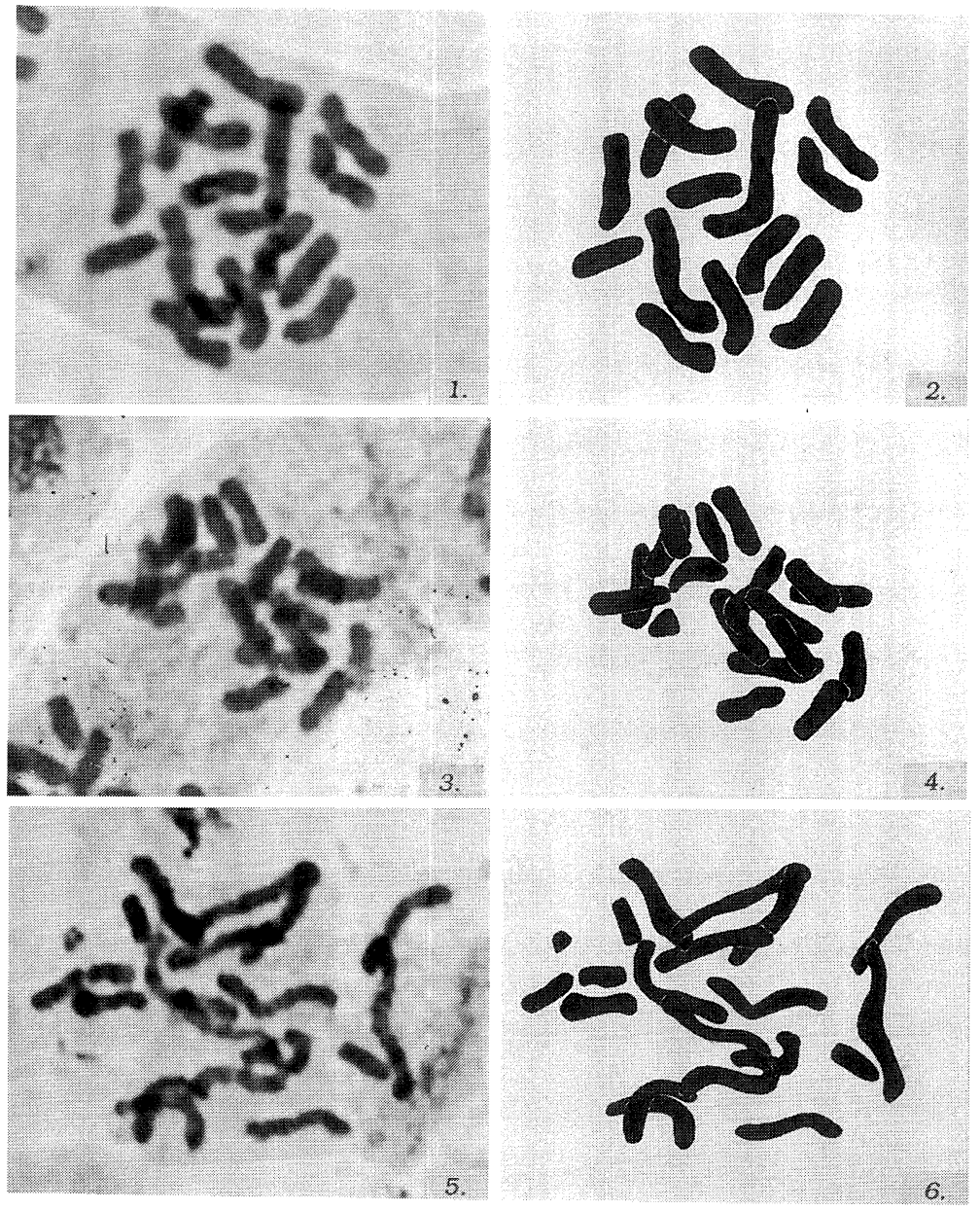

Figs. 1-6. Chromosome numbers at metaphase plate in Nitella hyalina f. hyalina $(\times 2400)$. 1) Chromosome number in Tighra plants $(n=15)$. 2) Reconstruction of Fig. 1. 3) Chromosome number of Mudasarilova plants $(n=18)$. 4) Reconstruction of Fig. 3. 5) Chromosome number in Sakhya Sagar dam plants $(n=21) .6)$ Reconstruction of Fig. 5.

small to large in the plants of Sakhya Sagar dam and Tighra dam but they are small to medium in Mudasarilova plants. The diameter of nucleolus is small in lowest chromosome number $(n=15)$ while large in highest chromosome number $(n=21)$ consisting plants. It shows some relationship between number of chromosomes and size of nucleolus (Table 2).

Karyotypic analysis shows that karyotype of Mudasarilova plant (Fig. 8) resembles the karyotype of Sakhya Sagar dam plant (Fig. 9) while the karyotype of Tighra plant (Fig. 7) differs with the karyotypes of these plants in lacking median chromosomes. It might be due to reduction in chromosome number from 18 or 21 to 15 . The origin of 15 chromosomal form leads the suspicion and might be through the hybridization between $n=12$ and $n=18$ chromosomal form of its polyploid races.

Polyploidy is certainly associated with the phenotypic variations. It is evidenced in the present observations on $N$. hyalina $\mathrm{f}$. hyalina. Cytotype with 21 chromosomes shows stalked gametangia and confluent to mucronate dactyls, whereas, the material showing 15 chromosomes was found to have stalked gametangia, mucronate dactyls and reticulate oospore wall ornamentation in contrast to the Mudasarilova plants which possess sessile gametangia, confluent dactyls and granulate 
oospore wall ornamentation characterised by 18 chromosomes. Rest of the characters in all the 3 cytotypes agree with the Wood (1965) description (Table 1).

A study of oospores wall ornamentation for various species of the genus Nitella was conductd by John and Moore (1978). They have been described the oospore wall ornamentation of the species $N$. hyalina as "finely punctate or granulate and often obscurely reticulate under light microscope. Under SEM it consists of anastomosing fibrils with loosely arranged fossa. They are occasionally flattened. These fibrils extend up onto the striae where they are more dense and often laterally fused. The 6 to 8 striae are thin but prominent and without a flange." It has to be mentioned here that these studies are based on herbarium and $4 \%$ formalin liquid preserved material de-

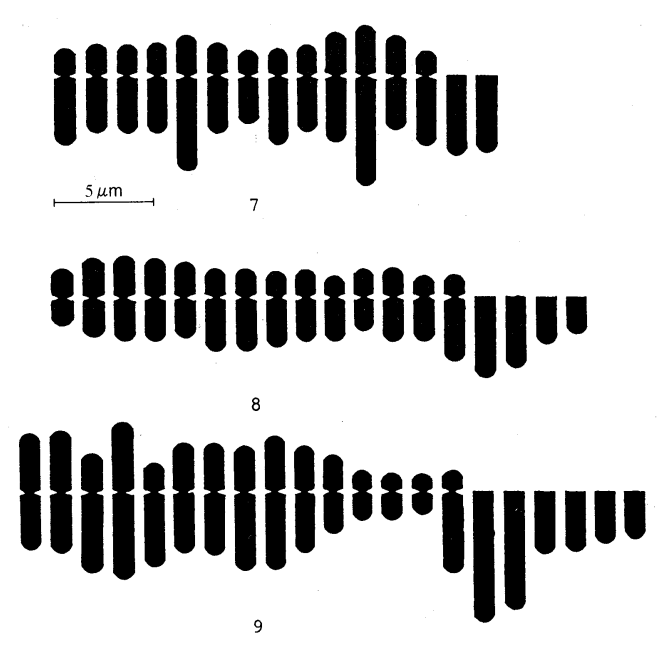

Figs. 7-9. Karyotypic organisation in Nitella hyalina $\mathrm{f}$. hyalina. 7) Karyotype of Tighra plants. 8) Karyotype of Mudasarilova plants. 9) Karyotype of Sakhya Sagar dam plants. posited in British Museum (Natural History), London. They were not subjected for cytomorphological studies and are arranged according to Braun (1882) on gross morphological features. There is possibility that they are randomly collected and might be mixed cytotypes of reticulate, granulate and finely granulate oospore wall ornamentation consisting plants bearing $n=15,18$ and 21 chromosomes, respectively, recorded during the present study.

\section{Acknowledgements}

Authors are grateful to Principal for providing necessary facilities and to C.S.I.R., New Delhi, for financial assistance.

\section{References}

Bhatnagar, S. K. 1988. Nitella hyalina f. hyalina (D.C.) Ag. RDW: A new chromosome count and its cytotaxonomy. Curr. Sci. 57: 343-344.

Braun, A. 1882. Fragmente einer Monographie der Characeen. Abh. Preuss. Akad. Wiss. 1: 1-211.

Caceres, E. J. 1975. Novedades Carologicas Argentinas I. Una nuera especie de Nitella Y tres adiciones al genero para al flora Argentiana. Kurtiziana 8: 105-125.

Comelles, M. 1984. El genere Nitella (Charophyceae) A Espanya. Bull. Inst. Cat. Hist. Nat. 51: 41-49.

Compere, P. 1982. Nitella euarthra new combination new status (Charophyta) rediscovered in South Africa (=N. tricuspis A. Br. var. euarthra A. Br.). J. South Afr. Bot. 48: 279-282.

Corillion, C. and Guerlesquin, M. 1972. Nitella claviformis nauvelle espice du genere Nitella (Charophycees). Bull. Soc. Et. Sci. Anjo. 8: 125-135.

Das, R. N. and Mazumdar, P. K. 1984. Chromosome number of Nitella from two districts (Purulia and Bankura) of West Bengal. Proc. Indian Sci. Cong. Assoc.: 15.

Faridi, M. A. F. 1956. A new species of Nitella from Pakistan. Biologia 2: 254-255.

Fu-shan, H. and Hualong, T. 1982. Two new species of Nitella from Guizhou. Nomica Sinica 20: 247-248.

Gillet, C. 1959. Nombres chromosomiques de plusiurs especes de Charophycees (Generes Nitella et Chara). Rev. Cytol. Biol. Veg. 20: 229-234.

Godward, M. B. E. 1948. The iron-alum. acetocarmine method for algae. Nature 161: 203.

Guerlesquin, M. 1961. Contribution a l'étude chromosomique des Charophycees d'Europe occidentale et d'Afrique du nord I. Rev. Gen. Bot. 68: 360-372. 
- 1963. Contribution a l'étude chromosomique des Charophycees d'Europe occidentale at d'Afrique du nord II. Rev. Gen. Bot. 70: $354-370$.

Hotchkiss, A. T. 1963. A first report of chormosome numbers in the genus Lychnothamnus (Rupr.) Leonh. and its comparison with other Charoophyte genera. Proc. Linn. Soc. N. S. W. 88: 368-372.

- 1965. Chromosome numbers in Characeae from South Pacific. Pacific Sci. 19: 31-37.

- and Imahori, K. 1987. A new species of Nitella (Characeae) belonging to the pleuricellulate species group in Australia. Proc. Linn. Soc. N.S.W. 110: 175-186.

John, D. M. and Moore, J. A. 1987. An SEM study of the oospore of some Nitella species (Charales, Chlorophyta) with descriptions of wall ornamentation and assessment of its taxonomic importance. Phycologia 26: 334-335.

Kanahori, T. 1971. Cytotaxonomical researches on the Characeae: Karyotype of the section Nitella of the genus Nitella. Bot. Mag. Tokyo 84: 327-334.

Khan, M. and Sarma, Y. S. R. K. 1967a. Studies on cytotaxonomy of Indian Charophyta II. Nitella Phykos 6: 48-61.

- and - 1967b. Some observations on the cytology of Indian Charophyta. Phykos 6: 62-74.

Mukherjee, S. 1978. Polyploid chromosome numbers in the genus Nitella. Curr. Sci. 47: 386.

— and Noor, M. N. 1973. A first report of karyological studies in Nitella wattii Groves from India. Science and Culture 39: 459-460.

Pundhir, H. S. and Gautam, A. 1993. Occurrence of Nitella hyalina var. hyalina f. brachyactis (A. Br.) Feldm. RDW: A new record for India. Phykos 32: 99-104.

- - - and Vidyavati 1993. Comparative study and new chromosome counts for Nitella hyalina var. hyalina f. indica (A. Br.) RDW. Phykos 32: 169-174.

- - - and - 1994. Some Charophytes from Aligarh district, Uttar Pradesh. Phykos 33: 1-9.

Ramjee and Bhatnagar, S. K. 1978. Significance of a new chromosome number in Nitella mirabilis Nordst ex Groves em RDW. Hydrobiologia 53: 99-101.

- and Sarma, Y. S. R. K. 1971. Some observations on the morphology and cytology of Indian Charophyta. Hydrobiologia 37: $367-382$.

Ray, S. and Chatterjee, P. 1988. Cytotaxonomical study of West Bengal Charophyta: A new chromosome number count of Nitella stuartii and its karyotype. Acta Bot. Neerl. 37: 523-525.

Sarma, Y. S. R. K. and Khan, M. 1964. Chromosome numbers in some Indian species of Nitella. Chromosoma (Berl.) 15: 246-247.

— and - 1965. A preliminary report on the survey of chromosome numbers of Indian Charophyta. The Nucleus 8: 33-38.

Sato, D. 1959. The protokaryotype and phylogeny in plants. Sci. Pap. Coll. Gen. Edu. Uni. Tokyo 9: 303.

Sawa, T. 1965. Cytotaxonomy of the Characeae: Karyotype analysis of Nitella opaca and Nitella flexilis. Amer. J. Bot. 52: 962-970.

Sinha, J. P. and Verma, B. N. 1970. Cytological analysis of the Charophytes of Bihar. Phykos 9: 92-99.

Stewart, L. M. 1937. Studies in the life histories of Nitella hyalina Agardh. J. Elisha Mitchell Sci. Soc. 53: 173-190.

Subramanian, D. and Ganesan, R. 1983. Cytotaxonomical studies of Charophyta from Tamilnadu. Proc. All India. Appl. Phyco. Cong., Kanpur: 184-191.

Wood, R. D. 1965. Monograph of the Characeae. In: Wood, R. D. and Imahori, K. (eds.). A Revision of the Characeae. Verlag Von J. Cramer, Weinheim, West Germany. pp. 904. 